\title{
A POESIA COMO DIEGESE: A PROPÓSITO DE REPÚBLICA 392d
}

\author{
Jacyntho Lins Brandão*
}

\begin{abstract}
Resumo: The paper focuses on the use of the term diegesis in Plato's Republic 392d, and presents a survey of the uses of the verb diegoumai in the previous authors and contemporaries of Plato. It shows that it should not be understood only as "to narrate", but as all kinds of account carried out by a diegetes. It concludes that the importance of defining precisely what characterizes the poetic diegesis comes from the fact that diegesis is also part of the lexis of historians, doctors, orators, and philosophers, but only the diction (lexis) of the poets is simply diegesis.
\end{abstract}

Palavras-chave: Platão, Teoria da Literatura, Poesia, Diegese.

Podemos sem dúvida considerar que o gesto inaugural da nossa teoria da literatura se encontra na República de Platão, quando Sócrates esclarece a Adimanto, que não compreendera a distinção entre lógos e léxis proposta pelo primeiro na derradeira etapa do exercício de diérese voltado para estabelecer qual seria a educação dos guardiões, nesses termos: "porventura tudo quanto é dito por contadores de histórias (mythológon) ou poetas (poietôn) não é diegese (diégesis) sobre coisas que foram, são ou serão (è gegonónton è ónton è mellónton)?” (República, 392 d).

Assim, é preciso admitir que o ponto de partida da sua (nossa) teoria está firmemente estabelecido na diégesis e será a partir da lógica da diegese que se desenvolverá. Nesse sentido, afasto-me de quantos, como Miner, consideram que é o teatro que cumpre esse papel, tomando como texto fundador a Poética de Aristóteles: o drama seria então "o gênero pelo qual Aristóteles deu origem à tradicional poética mimética do Ocidente" e "as propriedades do drama são aquelas que normalmente associamos à literatura do mundo ocidental de hoje" (Miner, 1996, p. 58). Ora, não se põe em dúvida que, também em Platão, a tragédia e a comédia exercem um papel importante na motivação e formulação da teoria, mas é equivocado entender que se trate de uma teoria sobre o teatro e não sobre a diegese (ou a "literatura") em geral. A razão, que pareceria para um grego muito simples, poderia ser formulada assim: afinal, tudo provém de Homero. O modelo (problemático) a cujas questões se busca responder está, portanto, na epopéia, o que é absolutamente evidente quando a reescritura dos versos iniciais da Ilíada fornece o exemplo do que se entende por "simples diegese". De Homero chega-se ao teatro, é verdade. Mas não seriam as propriedades do drama que se transportam para a epopéia e sim as desta para aquele, o qual, na lógica do modelo platônico, não deixa de ser (pelo menos teoricamente) derivado de Homero, que é mesmo chamado, com todas as letras, no ápice do último livro da República, de "primeiro mestre e comandante dos poetas trágicos" (tôn tragikôn prôtos didáskalós te kaì hegemón e tragoidían kaì tòn hegemóna autês Hómeron, República X, 595 c e 598 d, respectivamente). Acrescente-se que, mesmo em Aristóteles - ainda que as partes da Poética que se conservaram tratem, considerando-se a extensão, prioritariamente da tragédia - mesmo nele Homero se preserva como uma referência importante, se não a baliza principal. O que se constata, entretanto, é que não se parte mais da

\footnotetext{
"Professor Titular de Língua e Literatura Grega da Faculdade de Letras da Universidade Federal de Minas Gerais (UFMG). Bolsista de Produtividade em Pesquisa do Conselho Nacional de Desenvolvimento Científico e Tecnológico - CNPq.

${ }^{1}$ Analisei este experimento, partindo da sugestão de Spina (1994), em Brandão (2005).
} 
diégesis, mas da mímesis - constituindo isso a principal modificação aristotélica no modelo platônico. Não sem conseqüências para a posteridade, acrescente-se. Pois Homero, que em Platão era censurável por abusar da mimese, em Aristóteles se torna louvável justamente por usar dela abundantemente, já que o bom poeta passa a ser então o que mais mimetiza.

Mas o que supõe ou implica essa precedência e prevalência da diégesis em Platão? Podemos aventar, inicialmente, algumas hipóteses. Em primeiro lugar, uma mera constatação: a de que os gêneros não-diegéticos não se põem em causa, uma vez que a diegese é que define, do ponto de vista da léxis, o que pertence à poesia e à mitologia. Por outro lado, que os gêneros não-diegéticos não se entendem como questionáveis e, por isso, não há restrições a fazer quanto a eles, pelo menos no contexto da "reta constituição" (orthè politeía) que se elabora, visando à educação dos guardiões - ou simplesmente, nesse contexto, não vale a pena deles se ocupar. Terceiro ponto: se aos gêneros diegéticos se empresta tanta importância, é porque têm uma difusão muito ampla e um papel muito destacado na experiência "literária", desde a infância, exercendo uma função pedagógica. Finalmente, como está em causa a feitura (poíesis) da cidade justa, então têm eles também um impacto político digno de consideração. Que a abrangência desse impacto se estenda dos "mitos" que amas e mães narram às crianças às longas sagas heróicas que afetam o conjunto da pólis admite-se sem sombra de dúvidas: seu papel educativo desde a mais tenra idade é expressamente referido (República II, 377 c, 378 d etc.), enquanto também, através das perfórmances dos rapsodos, a recitação dos poemas se realiza como espetáculo para grandes multidões ${ }^{2}$.

Nesse contexto, o que hoje chamamos de teoria "literária" se diria, com mais exatidão, "teoria da diegese", entendendo-se que esta, em suas várias formas, seja capaz de englobar toda a literatura. Com mais exatidão: trata-se daquela espécie de discursos que, impondo questões do ponto de vista da recepção e dos efeitos, interessa à teoria, até porque, convém recordar, literatura é um termo que jamais existiu em grego, exigindo dos teorizadores, a cada momento, a explicitação de um recorte capaz de reunir o corpus sobre o qual se reflete. No caso de Platão, esse recorte se faz passo a passo, no contexto da educação tradicional: (a) a paidéia tradicional desdobra-se em (b) ginástica e música (mousiké); esta última, por sua vez, desdobra-se em (c) música (harmonía) e discurso (lógos); o qual se divide em (d) discurso (lógos) e dicção (léxis). Estamos diante do autêntico método platônico da diaíresis, em que, no interesse do diálogo, se fazem sucessivas divisões a fim de definir cada vez com mais precisão o que se encontra em debate (cf. Marques, 2006, p. 62-77).

\footnotetext{
${ }^{2} \mathrm{O}$ estatuto do rapsodo fornece o estofo para o Íon, em que se põe em cena um profissional especializado na apresentação dos poemas homéricos em festivais (cf. Íon, 531 a e 530 a, respectivamente), como o que acaba de acontecer em Epidauro, donde a personagem procede quando se encontra e dialoga com Sócrates. Embora o fio condutor da discussão seja a questão da tékhne (essa obsessão platônica de que não nos ocuparemos agora), faz-se toda uma reflexão sobre a recepção da poesia (neste caso, homérica), em que se destacam os fatos de que ela atinge grandes públicos e de que o rapsodo tem relações estreitas com o ator, enquanto um elo entre o poeta e os ouvintes. Em termos numéricos, referindo-se não a uma situação específica, mas verossímil, Sócrates chega a falar numa platéia de vinte mil pessoas! (Íon, 535 d) - provavelmente, ainda que não necessariamente, dispostas num teatro. A par disso, rapsodos e atores são intencionalmente aproximados, ainda por Sócrates, na comparação com os poetas - "sábios são vocês, os rapsodos, atores e aqueles de quem vocês cantam os poemas" (Íon, 532 d) - e a ironia que comporta a declaração de sua sabedoria (na contraposição com a ignorância socrática, que se reduz a dizer a verdade como uma pessoa inexperta) conduz, em seguida, à teoria da imantação, a partir da qual se explica o poder capaz de fazer com que o rapsodo, sendo nada mais que um intermediário entre o poeta e o público, possa agir sobre este último, (re)produzindo os efeitos provocados pelo primeiro. A solução é conhecida: assim como um ímã não só atrai anéis de ferro como também os imanta, e esses anéis, por sua vez, são capazes de atrair e imantar outros, o "poder divino" (theía dýnamis) procedente da Musa imanta o poeta, que imanta o rapsodo, que imanta o público (Íon, 533 e). Tomado de entusiasmo (no sentido etimológico), o rapsodo representa como um ator - é o que Sócrates quer demonstrar (para negar que a performance de ambos se deva ao domínio de uma arte): "Quão evidente, ó Sócrates, é essa prova que você me dá! Direi a você, pois, sem nada esconder: eu mesmo, quando digo algo lamentoso, de lágrimas enchem-se meus olhos; quando algo temível ou terrível, fíco de cabelos em pé de medo e o coração dispara." (Íon, 535 c) Ou seja: é justo admitir-se que o rapsodo é um verdadeiro ator que se apresenta sozinho e representa todas as personagens da diegese, além de o próprio narrador. Assim, nessa forma de efetivação espetacular, a diferença entre epopéia e teatro poderia ser definida a partir do número: um só ator para interpretar todas as personagens versus a distribuição de papéis que faz coincidir o número de atores com o de personagens. Conclusão: o teatro é uma forma de diegese, ao lado da epopéia - sobretudo a homérica, que se realiza também como uma das formas do drama -, ambos sendo os gêneros mais difundidos de diegese, os que têm maior impacto político e, conseqüentemente, levantam mais os problemas (sobretudo de recepção) a que a teoria busca responder.
} 
No nível da léxis é que será possível então afirmar que "tudo quanto é dito por contadores de mitos e poetas" é diegese, do mesmo modo que, na esfera do lógos, se afirmara que o mythos é, no todo, pseûdos (mentira, falsidade, ficção) em que há algo de verdade. Assim, se do ponto de vista do discurso (lógos) a "literatura" se define como ficção, da perspectiva da dicção (léxis) apresenta-se como diegese - e isso é o importante para entender-se a gênese da teoria dos gêneros. Não de todo e qualquer gênero de discurso, pois é razoável que, fora do contexto da diegese poética, haja outros tipos de dicção (de léxis), como as do retor, do historiador, do médico e, inclusive, a do filósofo.

Meu objetivo se concentrará aqui tão somente em buscar compreender o que Platão poderia estar entendendo por diegese, o que farei, num percurso apenas preambular, investigando os sentidos que o verbo diegeîsthai, tradicionalmente entendido como narrar, apresenta no corpus grego conservado até a época do filósofo. Com efeito, considerar que diégesis diga respeito apenas à narrativa tem levado teóricos e comentadores a admitir que Platão se tenha interessado só pelas "formas de poesia "narrativa', no mais amplo sentido da palavra", aquelas que Aristóteles, "ao inverter os termos, preferirá dizer 'mimética' ou representativa: aquela que 'conta' sucessos, reais ou fictícios", excluindo "toda poesia não-representativa, sobretudo o que chamamos de poesia lírica, e, com maior razão, qualquer outra forma de literatura (incluída ainda toda possível 'representação' em prosa, como nosso romance ou nosso teatro moderno)" (Genette, 1977). Declarações desse teor parecem, já à primeira vista, pouco exatas, bastando recordar que, na definição de Sócrates que nos interessa, tanto poetas quanto mythológoi (que são prosadores) estão em causa, do mesmo modo que, ao debater os problemas concernentes ao lógos dos poetas, de que a léxis se apresenta como mais um traço, em momento algum declara Platão que desconsidera a lírica.

Afirmei acima que meu percurso será preambular, pois não me ocuparei dos usos de diegeîsthai e seus derivados no próprio Platão, ao qual parece que se deva atribuir a invenção mesma do substantivo diégesis (a única outra ocorrência do mesmo, até sua época, encontrando-se no corpus hipocrático). Se, com o tempo, todos esses termos parecem ter adquirido um sentido cada vez mais especializado, nosso objetivo será aqui o de perceber o que circunda o exercício platônico, considerado como a fonte e origem dessa mesma especialização.

\section{DIEGEÎSTHAI}

Como já observei em outro trabalho, o que primeiro chama a atenção é o fato de que o verbo diegeîsthai e seus derivados diégesis, diégema e diegetés não se registram antes do século $\mathrm{V}$ a. C., o primeiro uso encontrando-se em Heráclito ${ }^{3}$. A partir de então o verbo entra em cena, passando a concorrer com outras palavras que cobriam a mesma esfera semântica, a mais antiga e importante das quais parece ser mytheîsthai, mas não menos importante sendo também légein, largamente utilizada por Heródoto para referir-se às diferentes narrativas que compilou.

O quadro abaixo apresenta a distribuição das ocorrências de diegeîsthai e seus derivados até a época de Platão (cf. o Thesaurus Linguae Graecae):

\begin{tabular}{|l|c|c|c|c|c|c|}
\hline & $\begin{array}{c}\text { Diegéoma } \\
i\end{array}$ & $\begin{array}{c}\text { prodiegéomai } \\
\text { ekdiegéomai } \\
\text { epekdiegéomai }\end{array}$ & adiégeton & eudiéget' & diégesis & diégema \\
\hline Andócides & 4 & 0 & 0 & 0 & 0 & 0 \\
\hline Antifonte & 4 & 0 & 0 & 0 & 0 & \\
\hline Aristófanes & 2 & 0 & 0 & 0 & 0 & 0 \\
\hline
\end{tabular}

${ }^{3}$ Cito o fragmento na tradução de Schüler (2000, p. 14-15): "Embora seja este o discurso (lógos), sempre, os homens tardam, não só antes de ouvi-lo, como logo que o ouviram; pois, mesmo que todas as coisas aconteçam de acordo com este discurso (lógos), mostram-se semelhantes a inexperientes ao experimentarem tais palavras e atos que eu persigo (diegeûmai) segundo a natureza distinguindo cada coisa e mostrando como ela é" (fragmento DK 22 B 1). Comentei o este texto em Brandão, 2007, p. 351-366. 


\begin{tabular}{|l|c|c|c|c|c|c|}
\hline $\begin{array}{l}\text { Corpus } \\
\text { hipocrático }\end{array}$ & 6 & 2 & 0 & 0 & 1 & 1 \\
\hline Epimênides & 1 & 0 & 0 & 0 & 0 & 0 \\
\hline Esopo & 7 & 0 & 0 & 0 & 0 & 0 \\
\hline Heráclito & 1 & 0 & 0 & 0 & 0 & 0 \\
\hline Heródoto & 0 & 1 & 0 & 0 & 0 & 0 \\
\hline Iseu & 1 & 0 & 0 & 0 & 0 & 0 \\
\hline Isócrates & 11 & 0 & 0 & 1 & 0 & 0 \\
\hline Lísias & 11 & 0 & 0 & 0 & 0 & 0 \\
\hline Platão & 47 & 3 & 0 & 0 & 21 & 0 \\
\hline Pródico & 2 & 0 & 0 & 0 & 0 & 0 \\
\hline Tucídides & 1 & 0 & 0 & 0 & 0 & 0 \\
\hline Xenofonte & 56 & 0 & 2 & 0 & 0 & 0 \\
\hline
\end{tabular}

Tabela 1: Ocorrências de diegéomai e seus derivados até a época de Platão

A variedade dos usos que esse corpus atesta apresenta-se a seguir, os empregos tendo sido classificados em dois níveis principais: a) aqueles relativos ao enunciado (basicamente os de terceira pessoa); b) aqueles relativos à enunciação (tanto de primeiro nível, ou seja, o autoral, quanto de segundo, referente ao discurso de personagens narradoras). A fim de evitar os problemas que o uso de narrar implica como tradução de diegeîsthai (e não são poucos nem de pouca importância), utilizarei, na classificação, o verbo português contar, já que é menos marcado e admite as acepções de narrar, relatar, expor e descrever.

\section{Nível do enunciado: ele conta}

Neste nível, os usos do verbo, considerando-se tanto seus complementos, quanto as situações, compreendem o diegeîsthai: a) um sonho; b) o que se viu; c) um acontecimento; d) um acontecimento, no Conselho ou na Assembléia; e) uma situação; f) um plano; g) o modo de ser de alguém; h) a beleza de alguém. Em uso intransitivo, registra-se ainda a ocorrência de diegeîsthai com alguém. Cada um desses usos detalha-se a seguir ${ }^{4}$.

\section{a) Diegeîsthai um sonho}

Um sentido bem marcado de diegeîsthai parece estar relacionado com a passagem das coisas vistas às ditas. Já o fragmento 1, 18 de Epimênides registra a acepção de contar um sonho (hýpnon diegeîto makrón), embora, tratando-se de citação, a ocorrência deva ser tomada com a necessária cautela. Todavia, na Anábase de Xenofonte encontramos um significativo exemplo, o qual nos garante a propriedade desse uso: em primeiro lugar, "Xenofonte teve um sonho" (literalmente, como se diz em grego: "viu um sonho", ónar eîden); em seguida, expõe-se o que ele sonhou: "parecia-lhe estar com os pés presos por cadeias e então as cadeias soltavam-se por si, de modo que, tendo-se libertado, podia ele caminhar quanto queria"; finalmente, vem a referência ao relato: "assim que começou a amanhecer, vai ele ao encontro de Quirísofo, diz que tinha esperanças de que tudo haveria de correr bem e conta-lhe (diegeîtai) o sonho" (Anábase, IV, 3, 8).

\section{b) Diegeîsthai o que se viu}

Como no que diz respeito aos sonhos, também em outros exemplos trata-se de passar algo da esfera do visto para o relatado. Ainda na Anábase, alguns jovens contam (diegoûntai), também a Quirísofo, que haviam visto um velho, uma mulher e algumas mocinhas atravessando um rio;

${ }^{4}$ Em Brandão, 2007, p. 351-366, apresentei este levantamento, comentando todavia apenas três dos usos nele registrados, comentários que, juntamente com os demais, reproduzo de novo aqui, em benefício de prover um entendimento mais detalhado da questão. 
diegoûnto aplica-se propriamente ao relato que eles repetiram para Quirísofo (diegoûnto tautá), sendo que, da primeira vez, quando descrevem o que viram ao próprio Xenofonte, o verbo que se usa é légein ("e então diziam que..." - kaì tóte élegon hóti... - Anábase, IV, 3 11-13).

\section{c) Diegeîsthai um acontecimento}

É o mesmo sentido que parece encontrar-se nas Vespas de Aristófanes: Bdelicleão conta como Eufidião, ainda que mais velho, lutou bravamente o pancrácio contra Ascondas, tendo uma forte couraça; Filocreão então pergunta como alguém lutaria o pancrácio com couraça, ao que responde o primeiro: "assim costumam contar os hábeis" (hoúto diegeîsthai nomízous' hoi sophoí - Vespas, 1996).

Nas fábulas de Esopo (mesmo que se reconheçam as dificuldades de atribuir-lhes uma datação segura), acham-se alguns exemplos importantes do mesmo uso. Nas três versões de $O$ lenhador $e$ Hermes, faz-se referência ao fato de o primeiro lenhador ter relatado, a seus companheiros, o que aconteceu em seu encontro com o deus, apresentando-se as seguintes variantes: "tão logo ele se aproximou dos companheiros, o que aconteceu lhes contou" (tà gegenémena autô̂s diegésato, Fábula 183, 1); "aproximando-se então dos seus companheiros, contou-lhes o que lhe aconteceu" (diegésato autô̂s tà symbánta autôi, Fábula 183, 2); "e ele, aproximando-se, tudo o que aconteceu contou de cabo a rabo aos companheiros" (pánta toîs hetaírois tà symbánta diexelélythen, Fábula 183, 3). Observe-se como, na terceira das versões, onde nas demais se encontra diegeîsthai, aparece diexérkhesthai (cujo sentido primeiro é atravessar, percorrer até o fim, donde provém a acepção de percorrer com a palavra, expor em detalhes). Também na fábula 254 lê-se uma expressão semelhante, neste caso conjugando diegeîsthai com légein: "ele, chegando de lá, aos companheiros diz tudo e por inteiro conta" (eis hetaírous legei tà pánta kaì diegeîtai hólos, Fábula 254 aliter). Ora, considerando-se que tà pánta pode ter um sentido adverbial (o que é mais provável), légein tà pánta (dizer por inteiro ou tudo) seria então um sinônimo muito próximo de diegeîsthai hólos (contar por inteiro), o que nos garante que se encontram na mesma esfera semântica - aliás, diegeîsthai parece ser uma opção menos comum, como já observei, numa esfera em que légein seria a mais corrente, ou seja, diante de légein, diegeîsthai parece ter uma marca intensiva, significando dizer detalhadamente, com precisão - o que corresponderia bastante bem ao termo português que venho privilegiando: contar.

d) Diegeîsthai um acontecimento no Conselho ou na Assembléia

Nas Helênicas de Xenofonte, é na situação de juízo que se afirma que, defendendo-se perante o Conselho, "os generais discorreram (diegoûnto) sobre a batalha naval e a enormidade da tempestade" (Helênicas, I, 7, 3), bem como, em seguida, diante da Assembléia, "contaram eles os acontecimentos" (tà pepragména diegoûnto): eles próprios iam atacar o inimigo e deram ordem de que homens capazes recolhessem os náufragos ainda com vida, fatos para os quais, em seguida, invocam o depoimento de testemunhas, a fim de provar que são acusados injustamente de incúria quanto a isso (Helênicas, I, 7, 3-5).

É também diante do Conselho que Andócides afirma que Pisandro relatou os acontecimentos como se deram (kaì tò prâgma éde pân diegeîto hos epéprakto), contando como ele, Andócides, havia socorrido a armada ateniense de Samos, fazendo com que tivesse sucesso contra os demais atenienses (Sobre seu retorno, 14). Neste caso, contudo, não se trata de fazer o relato dos acontecimentos para defender o envolvido, mas para acusá-lo (já que a armada de Samos era composta de democratas, contrários, portanto, aos Quatrocentos, que haviam tomado o poder em Atenas).

e) Diegeîsthai uma situação

Ainda nas Helênicas afirma-se que Epicididas foi enviado, pelos lacedemônios, até onde estava 
Agesilau, para pedir ajuda na iminência da guerra que se preparava, envolvendo beócios, atenienses, argivos e outros contra Esparta, e, "uma vez tendo lá chegado, ele tanto expôs (diegeîto) como estava a situação, quanto que a cidade mandava que socorresse a pátria o mais rápido possível" (Helênicas, IV, 2, 2). Como se vê, trata-se agora de expor algo, a fim de motivar uma decisão, na esfera da política.

\section{f) Diegeîsthai um plano}

Nas Aves de Aristófanes, diegeîsthai aplica-se a expor um negócio - na situação em que, tendo planejado construir a cidade dos pássaros entre o céu e a terra, de modo a poderem cobrar pedágio quando a fumaça dos sacrifícios subisse do mundo dos homens até a morada dos deuses, a Poupa e Pisetero concordam é que preciso "expor o plano" às outras aves (tís àn oûn tò prâgm' autô̂s diegésaito? - Aves, 198).

g) Diegeîsthai o modo de ser de alguém

Diegeîsthai pode também significar descrever o modo de ser de alguém, como acontece na Anábase: no curso da guerra, estando a ponto de ser morto um belo jovem trácio, Epístenes de Olinto, que era pederasta, suplica a Xenofonte que o poupe; este, então, dirigiu-se a Seutes para pedir-lhe que não matasse o jovem - "e descreveu o modo de ser de Epístenes (tô̂ Episthénous diegeîtai tòn trópon), bem como que, certa vez, reunira ele um batalhão observando nenhum outro critério senão que seus integrantes fossem belos" (Anábase, VII, 4, 7-8).

h) Diegeîsthai a beleza de alguém

Pode ainda o verbo ser empregado para falar da beleza física de alguém ou discorrer sobre ela, exemplo que se colhe também em Xenofonte, a propósito de uma hetera famosa:

Certa vez, havia na cidade uma bela mulher, cujo nome era Teódota, dessas que vão com quem as ganha. Como um dos presentes se recordasse (mnesthéntos) dela, dissesse (eipóntos) que sua beleza seria mais poderosa que o discurso (lógos) e falasse (phésantos) que à sua casa, para tomá-la como modelo, iam pintores, aos quais ela mostrava quanto era bela, - "Então é preciso ir e vê-la - disse Sócrates - pois aos ouvidos não é dado entender o que é mais poderoso que o discurso". E o que a tinha descrito (diegesámenos): - "Vocês não me seguiriam - disse ele - de imediato?" Em seguida, tendo-se dirigido à casa de Teódota e encontrando-a em pose para um pintor, viram-na (Memoráveis, III, 11, 1-2).

Observe-se o que o diegesámenos (o narrador) acabara de fazer para merecer essa denominação, ou seja, o que se inclui na esfera de seu relato: ele diz da beleza da mulher e fala sobre como sua casa era freqüentada por pintores. Assim, parece que não se trata propriamente de descrever a mulher (inclusive por que se admite que o discurso seria insuficiente para tanto), mas de louvá-la, apresentando um argumento (sua beleza tem mais força que o discurso) e uma prova (por isso os pintores a freqüentam).

\section{i) Diegeîsthai com alguém}

Registra-se pelo menos um uso intransitivo de diegeîsthai, na Fábula 301 de Esopo, O ladrão e o hoteleiro. O ladrão, pondo em prática o plano que elaborara para roubar o manto de quem o hospedara, afirma o narrador, "sentou-se perto do hoteleiro e começou a conversar com ele (érxato diegeîsthai met'autoû); e, conversando eles durante um tempo suficiente (diegoúmenoi hóran hikanén), o ladrão lançou-se ao chão e, ao mesmo tempo que se lançou, uivou como um lobo" (Fábula 301). É provável que diegê̂sthai signifique, mais exatamente, neste contexto, contar histórias, contar casos (como se diria no sertão, prosear com alguém, o que geralmente supõe ou, 
pelo menos, engloba os casos que se contam).

\section{Nível da enunciação: eu conto}

Com relação a estes usos, é necessário proceder a uma dupla distinção: de um lado, encontramse ocorrências de enunciação em primeiro grau, quer dizer, autoral, destinada a explicitar, da parte do autor, que ele, enquanto enunciador, narra, relata ou expõe algo; por outro lado, encontramos enunciações de segundo grau, quando alguma personagem, representada em primeira pessoa, esclarece, como enunciadora de um discurso, que expõe, relata ou narra ${ }^{5}$.

Em primeiro lugar apresentam-se os exemplos de primeiro grau, isto é, a enunciação autoral, em que se registram usos de digê̂sthai relativos aos seguintes temas: a) a natureza, o corpo, a saúde e a doença; b) os acontecimentos, num tribunal; c) quantas coisas, também num tribunal; d) motivações, ainda num tribunal; e) fatos históricos; f) uma vida.

a) Diegeîsthai a natureza, o corpo, a saúde e a doença

A conjunção entre a diegeîsthai e descrever (que discorrer, relatar ou expor podem significar com bastante propriedade em português) confirma-se bem nos usos do corpus hipocrático. Assim, em Sobre os ares, as águas e os lugares, afirma o autor que "desejo discorrer sobre o restante das águas" (perì dè tôn loipôn hydáton boúlomai diegésasthai), esclarecendo que tratará "tanto das que são doentias, quanto das saudáveis, de quais águas vêm a ser naturalmente más e de quantas são boas" (Sobre os ares, as águas e os lugares, 7, 1). Como se vê, está em jogo o separar e distinguir como base para diegeîsthai, o que se repete em Da dieta, quando se afirma que, "a respeito dos sofrimentos, que tipo de poder (dýnamin) eles têm, exporei (diegésomai)", passando-se imediatamente à prometida exposição: "pois se há os que são naturais, há também os que se devem à violência" (eisì gàr hoi mèn katà phýsin, hoi dè dià bíes - Da dieta, i-iv, 61, 1). Noutro ponto, a propósito da fecundação, afirma-se: "como vejo que é a fecundação no sexto dia, exporei (diegésomai)", dando-se início a uma detalhada narração ( $D a$ inseminação, da natureza das crianças e das doenças, iv, 13, 4).

No livro sobre as articulações procede-se a um comentário de ordem metatextual bastante importante para nossos propósitos, quando se declara que "ainda que não seja fácil relatar com precisão (atrekéos diegéesthai), por escrito, toda a cirurgia, deve ele [o leitor] fazer dela uma idéia (hypotopéesthai), a partir do que foi escrito" (Das articulações, 33, 7). Assim, opõe-se, de um lado, o que se diria de um modo preciso, através do relato, ao que não se faz dessa forma, sendo necessário, por isso, contar com a suposição de quem lê.

Encontramo-nos, com efeito, numa esfera em que a exatidão com que se relata e se entende é absolutamente relevante, pois o médico deve basear-se não só no que se encontra exposto nos livros, mas igualmente, enquanto praticante duma tékhne, no que lhe expõe, inclusive através do discurso, o doente que tem diante de si. Em Das doenças do povo, a propósito da orientação do enfermo (he perì tòn nosoûnta oikonomíe) e do que lhe perguntar sobre a doença (es tèn noûson erótesis), arrolam-se, como instrumentos, "as coisas que ele relata, quais são, como se deve compreendê-las, e os discursos" (hà diegeîtai, hoîa, hos apodektéon, hoi lógoi - Das doenças do povo, 6, 2, 24, 2).

b) Diegeîsthai os acontecimentos no tribunal

É provável que a especialização de diegê̂sthai como fazer uma narrativa de fatos - o nosso sentido comum e restrito de narrar - tenha se dado numa outra esfera igualmente sensível para a

\footnotetext{
${ }^{5}$ Entendo por enunciação "a unidade semântica e sintática constituída pela predicação, a proposição e os elementos que expressam valorações subjetivas do emissor referidas a seu próprio ato de fala (como a justificação, o fim ou a causa), bem como à organização do discurso" (Crespo et al., 2003, p. 12).
} 
exatidão das palavras (em que está também em jogo o futuro e a vida dos envolvidos): a dos tribunais.

Os exemplos são inúmeros. Comecemos pelos mais típicos: "a respeito dos acontecimentos tentarei narrar-vos a verdade" (perì dè tôn genoménon peirásomai hymîn diegésasthai tèn alétheian - Antifonte, Contra a madrasta, 13, 8); "julgo digno, antes de tudo, sobre o próprio assunto responder e narrar tudo que aconteceu entre vós" (egò dè axiò prôton mèn perì autoû toû prágmatos apokrínesthai, kaì diegésasthai en hymîn tà genómena pánta - Antifonte, Do dançarino, 8, 2); "pois é preciso narrar-vos estas coisas" (dề gàr taûth' hymîn diegésasthai - Lísias, 1, 9, 2); "em primeiro lugar quero narrar o que se passou no último dia" (prôton dè diegésasthai boúlomai tà prakhthenta têi teleutaíai hemérai - Lísias, 1, 22, 3); "não subtraindo nada, narrar-vos-ei tudo que se fez" (oudèn apokrypsámenos hápanta diegésomai pròs hymâs tà pepragména - Lísias, 3, 3, 6); "deste ponto começo a narrar-vos" (enteûthen hymîn árxomai diegeîsthai - Lísias, 13, 4, 7; Isócrates, Egineta, 4, 10); "narrar-vos-ei" (diegésomai d’hymîn - Andócides, Contra Alcibíades, 25). Também as declarações de brevidade servem para introduzir uma narrativa: como tal coisa ocorreu, "narrarvos-ei com a maior brevidade de que seja capaz" (diegésomai hymîn hos àn dýnomai dià brakhytáton - Isócrates, Eutino, 2, 2).

Em todos os casos o que se observa é que diegeîsthai supõe um relato ordenado, no sentido da norma que Hermógenes atribui a Isócrates: "pois também Isócrates, em sua arte retórica, diz que, na narração (diegései), deve ser dito o acontecido, os antecedentes, as consequiências e os desígnios" (tó te prâgma kaì tà prò toû prágmatos kaì tà metà tò prâgma kaì tàs dianoías - Isócrates, fr. 6.1, Walz) - e, ainda, que "se deve narrar o que aconteceu em primeiro lugar, em segundo lugar e o restante seqüencialmente" (diegetéon dè tò prôton kaì tò deúteron kaì tà loipà hepoménos - fr. 10, 12).

c) Diegeîsthai quantas coisas num tribunal

Um torneio comum, que poderia ser classificado no âmbito dos recursos retóricos, é o que afirma que longo seria contar algo. Todavia, deve-se ressaltar que, nesses casos, parece que está em causa uma enumeração, conforme se registra em Lísias: "quantas coisas foram ditas aqui, longo seria enumerar" (hósa mên autóthi erréthe, polys àn eíe moi lógos diegeîsthai - Lísias, 23, 11); também em Andócides: "nós tínhamos a Queronésia, Naxos e mais de dois terços da Eubéia quanto às outras colônias, longo seria enumerá-las uma a uma" (tás te állas apoikías kath’hékaston diegeîsthai makròs àn eíe lógos - Andócides, Sobre a paz, 9).

\section{d) Diegeîthai motivações num tribunal}

Essa acepção está naturalmente conectada com a anterior: a diferença seria apenas que, em vez de referir-se a uma relação de dados ou fatos, o sentido parece ser o de uma exposição dos motivos que impulsionam determinada ação ou personagem (ainda que essa exposição comporte sim a referência a dados ou fatos, como é próprio do tribunal). É em Sobre os mistérios que, defendendose, Andócides afirma: "Eia, cidadãos (pois quereis logo ser informados disto), Cálias depôs o ramo de suplicante desejando o quê? Eu próprio vos exporei a causa por que ele maquinou contra mim (egò diegésomai hôn hyp'autoû héneka epebouleúthen - Sobre os mistérios, 117).

\section{e) Diegeîsthai fatos históricos}

Com os historiadores, deparamo-nos com um grupo de escritores cuja especialidade é a narrativa: o que então primeiro salta à vista é como diegeîsthai não faz efetivamente parte do vocabulário de Heródoto e Tucídides.

A única ocorrência no primeiro encontra-se no livro VI das Histórias, quando, a propósito de Megabazo, o narrador diz: "este, por seu turno, fez então isso; por outro lado, houve, ao mesmo tempo, na Líbia, uma outra grande expedição dum exército, com o pretexto que eu descreverei em 
detalhes (apegésomai), tendo antes narrado isto" (prodiegesámenos próteron táde - Histórias, IV, 145). A sentença se encontra no justo limite que marca o fim do lógos cita e o começo do líbio, estabelecendo uma oposição significativa entre apegéesthai e (pro)diegéesthai: se o pretexto será detalhado, isto é, exposto desde o início, a que se referirá a narrativa propriamente dita? De um lado, considerando-se que o lógos cita comporta tanto a descrição dos costumes desse povo, quanto a narrativa da guerra que contra eles empreendeu Dario, ao lógos líbio poderia aplicar-se o mesmo raciocínio, compreendendo o prodiegéesthai tanto a narrativa da colonização da Líbia pelos lacedemônios e a sucessão de seus descendentes no poder, que dá pretexto à guerra feita por Ariando contra os líbios (Histórias, IV, 145-167), quanto a descrição do país (Histórias, IV, 168205). Por outro lado, tendo-se em vista o que se afirma em 167 (haúte mén nyn aitíe próskhema tô̂ lógou egíneto, apepémpeto dè he stratié, hos emoì dokéein, epì Libýon katastrophêi - esta presente causa, por um lado, torna-se o pretexto do lógos, e [Ariando], por seu turno, enviou o exército, como me parece, para a destruição dos líbios), tendo-se isso em vista pode-se considerar que o prodiegéesthai se referiria apenas à narrativa que desemboca na declaração do pretexto, sem incluir a descrição da Líbia, ou seja: é através do diegéesthai, que remonta no tempo para encontrar as motivações, que se descreve em detalhes o pretexto (apegéesthai).

A ocorrência de diegeîsthai em Tucídides refere-se ao episódio do assassinato de Hiparco por Harmódio e Aristogíton, que servira de exemplo para mostrar como os atenienses, tal qual os outros homens, aceitam as tradições do passado "sem submeter a prova sua autenticidade" (A Guerra do Peloponeso, I, 20). É por isso que, no livro VI, 54-59, ele retoma os fatos, abrindo suas considerações assim: "pois o feito corajoso de Aristogíton e Harmódio foi executado em vista duma circunstância amorosa, com o que eu, após tê-la narrado detalhadamente (epì pléon diegesámenos), demonstrarei que nem os outros [gregos], nem os próprios atenienses, a respeito de seus próprios tiranos ou do que aconteceu, nada dizem de exato". A narrativa trata então da paixão de Aristogíton por Harmódio, de como este passa a ser acossado por Hiparco para que lhe concedesse também seus favores, de como os dois amantes decidem vingar-se, matando não só Hiparco, mas também o tirano Hípias, irmão daquele, durante a procissão das Grandes Panatenéias, e de como, então, por julgarem que haviam sido traídos, atacam apenas Hiparco e o matam, o que provoca a vingança de Hípias e o recrudescimento duma tirania até então branda para com os cidadãos. Como se vê, além duma simples narrativa, trata-se de expor com precisão os acontecimentos, elucidando causas e conseqüências, de modo a corrigir a versão comum que creditava aos dois amantes o alto feito de terem dado morte ao "tirano" Hiparco, que, entretanto, nunca o teria sido (pois fora Hípias que sucedera a Pisístrato, enquanto seu filho mais velho). O que o relato de Tucídides tem em comum com o de Heródoto é o desejo de prover uma informação acurada sobre determinado fato em que se encontram as razões de desdobramentos penosos, corrigindo-se outras versões.

Ainda na seqüência dos narradores por vocação encontramos Xenofonte, em que se registra o maior número de ocorrências de diegeîsthai - o único dos autores contemporâneos ou mais antigos que, na quantidade delas, ultrapassa Platão. O caso ganha em importância (ou, quando menos, curiosidade) se tivermos em vista que se trata, como Platão, de um dos "biógrafos" de Sócrates, o que em princípio relacionaria com o círculo socrático o interesse pela diegese, talvez pela própria necessidade de, nesse contexto, discernir os vários tipos de testemunhos que circulavam sobre o "mestre". Com efeito, se, por um lado, a "tradição" socrática transmite-se como um corpus de relatos sobre lógoi (ou diálogoi), também é verdade que, num plano mais amplo, pereniza o próprio julgamento que condenou o filósofo - e já vimos como, na esfera do tribunal, diegê̂sthai tem uma função importante no sentido de permitir que se decida sobre aquilo que não pode ser constatado e, conseqüentemente, de que não se conta senão com versões conflitantes.

São significativos os usos metatextuais que Xenofonte faz de diegeîsthai enquanto narrador em primeira pessoa. A propósito da batalha de Coronéia, em que Agesilau enfrenta os aliados, ele observa: "este era o poder (dýnamis) de ambos os lados" - para concluir, após ter descrito os dois 
exércitos, que - "descreverei (diegésomai) também a batalha e como ela foi tal qual nenhuma outra do nosso tempo" (Helênicas, IV, 3, 16). Ainda nas Helênicas encontramos outras observações de teor semelhante: "tal era, pois, sobre a terra, o curso da guerra; o que, enquanto isso, se passava no mar e nas cidades litorâneas relatarei (diegésomai) e, das ações (praxéon), as dignas de memória escreverei (grápso), deixando de lado as indignas de serem relatadas (tàs mè axías lógou Helênicas, IV, 8, 1); mais à frente, a propósito de Telêutias, reconhece "que não relato (diegoûmai) aqui nenhum gasto de dinheiro, nem perigo, nem estratagema notável (axiólogon)", sendo justamente por isso que se deve perguntar o que teria feito o general para inspirar o respeito e admiração de que gozava entre seus subordinados (Helênicas, V, 1, 4).

\section{f) Diegeîsthai uma vida}

Da história, a passagem para a biografia não se apresentará, do ponto de vista do gênero de discurso, como despropositada. Para não nos estendermos nos inúmeros exemplos, vale citar apenas o fim do prefácio da Ciropedia, que não deixa de definir a obra como um longo relato:

Nós, por julgarmos este homem digno de admiração, investigamos qual era sua linhagem, qual natureza ele tinha e por qual paidéia tendo sido educado tornou-se assim eminente para governar homens. Quanto soubemos e cremos ter sabido sobre ele, isso tentaremos relatar (hósa oûn kaì epythómetha kaì esthêsthai dokoûmen perì autoû, taûta peirasómetha diegésasthai) (Xenofonte, Ciropedia, 1, 1).

As Memoráveis fornecem-nos igualmente exemplos do uso de diegeîsthai, dessa feita no contexto da polêmica em torno de Sócrates - ou, talvez com mais exatidão, da perenização de seu julgamento. Ao rebater, no segundo capítulo do livro 1, o argumento, usado pelos acusadores no tribunal, de que Sócrates corrompia a juventude, apresentando-se como prova os exemplos de Crítias e Alcibíades, Xenofonte declara:

Disse o acusador: Crítias e Alcibíades, tendo sido discípulos de Sócrates, os maiores males fizeram à cidade: Crítias, com efeito, dentre todos que participaram do regime oligárquico [isto é, da Tirania dos Trinta], foi o mais ladrão, violento e assassino; Alcibíades, por seu lado, dentre todos que tomaram parte no regime democrático, foi o mais intemperante, insolente e violento. Eu, se algum mal à cidade eles fizeram, não os defenderei - mas como foi a convivência de ambos com Sócrates exporei (diegésomai) (Memoráveis, I, 2, 12-13).

A exposição estende-se até o parágrafo 48, admitindo a reprodução de dois breves diálogos (de Cáricles com Sócrates e de Alcibíades com Péricles), mas o que prevalece é sem dúvida o gênero argumentativo: nem porque Crítias e Alcibíades foram discípulos de Sócrates na juventude se poderiam imputar a este os erros que cometeram, até porque, observa-se na conclusão, "também Críton foi discípulo de Sócrates, bem como Querefonte, Querécrates, Hermógenes, Símias, Cebes, Fedondas e outros que com ele conviveram não a fim de se tornarem políticos e juízes, mas para que, tornando-se de caráter nobre (kaloí te kagathoî), pudessem agir bem com relação a sua casa, servos, familiares, amigos, cidade e cidadãos" (Memoráveis, II, 2, 48) ${ }^{6}$.

\section{g) Diegeîsthai um argumento}

É a mesma situação polêmica que marca outros usos de Xenofonte, nas Memoráveis, sempre a respeito de Sócrates, o que faz com que as narrativas de seus embates com outros interlocutores assumam um caráter fortemente argumentativo (elas poderiam, de todo direito, constar de um

\footnotetext{
${ }^{6}$ Sobre a importância desse tipo de argumento com relação ao julgamento de Sócrates e à polêmica que a ele se segue: Canfora, 2003, p. 17-36.
} 
discurso de defesa num tribunal, mesmo que se trate, apenas, de memórias).

Assim, para tomar apenas dois exemplos, afirma o narrador: "que ele era útil àqueles que visam às coisas belas e, com cuidado, fazem aquilo a que visem, agora isso exporei" (nyn toûto diegésomai - Memoráveis, III, 1, 1); "como ele se contrapunha aos que consideravam ter recebido uma educação excelente e se vangloriavam de sua sabedoria agora exporei (nyn diegésomai Memoráveis IV, 2, 1). Como se vê, trata-se de diegeîsthai "que ele era útil" e "como se contrapunha". O que segue são, respectivamente, os relatos dos embates de Sócrates com Dionisodoro e Eutidemo, que não constituem, todavia, mera narração dos mesmos, pois a observação de abertura do narrador garante que se tomam na qualidade de uma peça a favor do filósofo.

\section{h) Diegeîsthai perfórmances (de Sócrates)}

Ainda das Memoráveis registre-se o uso concernente às perfórmances de Sócrates nas discussões: "outros, portanto, relataram (diegoûnto), estando presentes quando ele conversava assim com outros; mas eu, quando com Eutidemo ele discutiu (dielégeto) tais coisas [a respeito dos deuses], estive presente" (Memoráveis, IV, 3, 2-3).

O que há de importante neste caso é que se trata de relatos de diálogos, como encontramos também em Platão.

i) Diegeîsthai um caráter (o de Sócrates)

O epílogo das Memoráveis é bastante eloqüente quanto às intenções de Xenofonte, na medida em que resume o que se relatou no conjunto da obra, ou seja, o caráter de Sócrates:

Dentre os que conheceram Sócrates, como ele era, todos os que visam à virtude ainda agora passam a vida tendo saudades, mais que de tudo, dele, na qualidade de alguém que era utilíssimo para o cuidado com a virtude. A mim, pois, sendo ele tal qual eu expus (diégemai) - assim piedoso, de forma a nada fazer sem a vontade dos deuses; justo, de modo a não prejudicar ninguém, mesmo que em algo pequeno, e ser ao máximo útil aos que dele necessitavam; mestre de si de forma a jamais escolher o mais agradável em vez do melhor; prudente, de forma a não errar ao discernir entre as coisas melhores e as piores, sem de outro ter necessidade, mas sendo autárquico com relação ao conhecimento; hábil também no julgar os outros, pôr à prova os que erram e fazê-los voltar-se para a virtude e a nobreza de caráter - a mim, portanto, ele parecia ser tal qual deveria um homem excelente e felicíssimo. Mas se a alguém essas coisas não agradam, que o julgue, comparando-o com o caráter de outras pessoas (Xenofonte, Memoráveis, IV, 8, 11).

\section{Enunciação de segundo grau ou das personagens narradoras: eu conto}

O que há de relevante nesta esfera é que se procede à representação da enunciação autoral: uma vez que o enunciador-autor inclui em seu texto a representação de personagens que falam em primeira pessoa, ou seja, se apresentam elas também como enunciadoras, torna-se possível que explicitem que contam, expõem ou relatam algo. Trata-se, portanto, de um nível de enunciação submetida a processos miméticos - o que não é sem importância, sobretudo no que diz respeito aos "biógrafos" de Sócrates, especificamente Platão e Xenofonte, os quais, explorando os recursos que a mimese provê, fazem o mestre falar. Sobretudo no caso de Platão, que nos interessa de perto, uma vez que é a ele (ou mais exatamente, a seu Sócrates) que se deve a primeira teorização sobre a diégesis - e é para entendê-la, recorde-se, que estamos perfazendo esse percurso investigativo sobretudo com relação a ele, Platão, não se pode perder de vista que se trata de um enunciador que jamais se expressou diretamente enquanto autor, mas delegou todo discurso a enunciadores de segundo grau, seja na forma dialógica, seja em registro narrativo.

Um caso exemplar desse tipo de procedimento encontra-se, ainda uma vez, nas Memoráveis de 
Xenofonte, quando é o próprio Sócrates quem relata a Aristipo o episódio da escolha, por Héracles, dos dois caminhos (conforme o que escrevera Pródico): o herói, na passagem da infância para a juventude, não sabia se escolheria o caminho da virtude ou do vício; aparecem-lhe então duas mulheres, a Virtude e o Vício personificados, que tentam convencê-lo a optar pelas respectivas vias; esta última expõe, em primeiro lugar, as vantagens e facilidades que proporciona a quem a elege; chega então a vez de a Virtude manifestar-se, o que ela faz dizendo:

Não o enganarei com proêmios lisonjeiros, mas, como os deuses estabeleceram-nas, exporei as coisas com verdade (tà ónta diegésomai met'aletheías), pois do que é bom e belo nada os deuses dão aos homens sem fadiga e preocupação: se você quer que os deuses lhe sejam propícios, é preciso servir os deuses; se você quer ser amado pelos amigos, é preciso beneficiar os amigos; se você deseja ser honrado por alguma cidade, é preciso ser útil à cidade; se você deseja ser admirado por toda a Grécia em vista de sua virtude, é preciso tentar fazer bem à Grécia; se você quer que a terra lhe traga frutos irrepreensíveis, é preciso cuidar da terra; se você julga dever enriquecer-se com os rebanhos, é preciso preocupar-se com os rebanhos; se você quer também pelo desejo da guerra crescer, para poder libertar os amigos e prejudicar os inimigos, é preciso aprender a arte da guerra com os entendidos e exercitar como deve ser utilizada; e se você quer também ter um corpo vigoroso, para que sirva à mente, é preciso habituar o corpo a isso e exercitá-lo com fadiga e suor (Xenofonte, Memoráveis, II, 1, 27-28).

Citei a íntegra do que a Virtude anunciou que exporia, para que se perceba como o conteúdo, neste caso, se realiza como uma série de conselhos, articulados em forma de hipóteses sobre desejos e os requisitos para sua realização (se você quer..., então é preciso...), no registro do gênero exortativo ou parenético, ou seja, trata-se de um discurso voltado claramente para o tempo futuro (e recorde-se, a propósito, como esta possibilidade - de que a diegese de contadores de mitos e poetas seja sobre o futuro - é admitida por Platão). Que se trata de uma diégesis não parece haver dúvidas, pois, tão logo a Virtude fecha sua exposição, "o Vício, retrucando, fala (como diz Pródico): Medite, ó Héracles, como esta mulher lhe expõe (diegeîtai) um caminho difícil e longo para a alegria; eu, de minha parte, por um caminho fácil e rápido o conduzirei à felicidade." (Memoráveis, II, 1, 29)

Modificando o método até aqui utilizado, no interesse de examinar, no seu conjunto, mais um exemplo socrático não-platônico, transcrevo as ocorrências de diegéomai no Econômico de Xenofonte (valendo-me da tradução de Prado, com a intenção de evitar que a análise se torne viciada por minhas próprias opções de entendimento dos termos). Com efeito, é neste texto que se observa uma das maiores concentrações do citado verbo na obra de Xenofonte. ${ }^{7} \mathrm{O}$ que tenho em vista é simplesmente verificar como se utiliza o termo em questão numa obra que supõe vários níveis enunciativos: a) o do narrador (voz autoral); b) o dos que dialogam (Sócrates e Critobulo); c) o dos que dialogam em segundo nível, no diálogo narrado por Sócrates a Critobulo (Sócrates e Iscômaco).

O narrador de primeiro nível (que, em princípio, se identifica com o próprio autor, manifesta-se diretamente no breve prólogo ("eu o ouvi, um dia, conversando (dialegoménou) sobre a economia, nestes termos"), mantendo sua presença, através dos verbos dicendi (ele disse, disse Sócrates, disse Critobulo), até o sétimo capítulo - ou seja, até mais ou menos o primeiro terço da obra - quando então passa a dividir a função narrativa com Sócrates, que se manifesta, enquanto narrador, entremeando ele também, além de pequenos trechos propriamente narrativos, os verbos dicendi (eu disse, ele/Iscômaco disse) às suas falas e às de seu interlocutor. A diferença entre as duas partes está

${ }^{7}$ Ciropedia, 15 ocorrências; Econômico, 11; Memoráveis, 9; Helênicas, 7; Anábase, Agesilau e República dos lacedemônios, 3 vezes em cada; Sobre as rendas, 2; Hierão, Hiparco e Sobre a equitação, 1 registro em cada;, há obras em que não se descobre nenhuma ocorrência de diegéomai: dentre as socráticas, Banquete e Apologia de Sócrates; nas demais, Cinegético e República dos atenienses. 
em que, na primeira, o narrador não participa, como personagem, do diálogo (não podendo, portanto, jamais usar "eu disse"), enquanto, na segunda, já que Sócrates relata seu diálogo com Iscômaco, expõe o que disse tanto este último, quanto ele próprio.

Apesar de que, portanto, todo Econômico possa ser classificado como a narrativa de um diálogo em que se narram outros diálogos enquadrados, os usos específicos de diegéomai são os que se indicam a seguir:

a) "Pois bem, conta-se (légetai) ainda que Ciro, quando Lisandro veio trazer-lhe os presentes da parte dos aliados, recebeu-os muito gentilmente, de acordo com o que o próprio Lisandro [disse (éphe), contando-o (diegoúmenos)] um dia a um hóspede de Mégara, e, o que foi melhor, [disse (éphe) ele], mostrou-lhe o paraíso que possuía em Sardes" (Econômico, IV, 20). Trata-se de fala de Sócrates, dirigida a Critobulo, no primeiro nível do diálogo narrado. ${ }^{8}$

b) "Esses fatos, Critobulo, eu narro (diegoûmai), disse Sócrates, porque nem os mais prósperos podem manter-se afastados da agricultura" (Econômico, V, 1). O "eu narro" se deve a Sócrates, que continua a tratar do episódio envolvendo Lisandro e Ciro; "disse Sócrates" se deve ao narradorautor de primeiro nível.

c) "O que acharás, Critobulo, disse (éphe) Sócrates, se eu te contar desde o começo (ex arkhês diegésomai) o encontro que, um dia, tive com um homem que, na minha opinião, está entre esses que realmente merecem o nome de homem belo e bom? (...) Pois bem! eu te contarei (léxo), disse (éphe) Sócrates, como vim a poder observá-lo" (Econômico, VI, 12). As duas falas de Sócrates, identificadas como tal pelo narrador-autor, preparam a passagem para o diálogo em segundo nível, a ser narrado pelo próprio filósofo, ou seja, sua conversa com Iscômaco, o homem que merece ser chamado de kalòs kagathós.

d) "Pelos deuses, Iscômaco! [disse (éphen) eu.] Conta-me (diegoû moi) o que lhe ensinaste em primeiro lugar. É isso que eu gostaria de ouvir-te contar (diegouménou) e muito mais que de ouvirte falar (diegô̂o) sobre a mais bela competição de ginástica e hipismo" (Econômico, VII, 9). Após ter relatado como recebera sua mulher ainda inexperiente no comando da casa, Iscômaco assume a função narrativa, para relatar como a instruiu; o trecho comporta tanto os discursos diretos do marido, que é também o narrador, quanto os de sua mulher, sem jamais perder de vista que se trata de uma narrativa enquadrada, pois o narratário permanece explícito através dos vocativos, como, por exemplo, em VII, 14, quando se diz, introduzindo-se o discurso direto da esposa: "a isso, Sócrates, minha mulher respondeu".

e) "E eu, disse Sócrates, ao ouvir que a mulher lhe havia dito isso, falei: - Por Hera! Iscômaco, disse eu, quão viril mostras ser a mente de tua mulher! - Pois bem! disse Iscômaco. Quero expor-te (diegésasthai) exemplos de sua grandeza de alma em ocasiões em que bastou ouvir-me uma só vez para obedecer-me prontamente" (Econômico, X, 1). Belo exemplo de como os níveis narrativos interagem: a expressão "disse Sócrates" se deve ao narrador-autor, que relata o diálogo daquele com Critobulo; "disse eu" e "disse Iscômaco" se devem ao narrador de segundo nível, ou seja, Sócrates, que relata a Critobulo seu diálogo com Iscômaco.

f) "Neste ponto, disse-lhe eu: - Iscômaco, penso que, por agora, a respeito dos trabalhos de tua mulher, ouvi o bastante e aliás, por eles, ambos merecem elogios. Agora, porém, [disse (éphen) eu,] fala-me (lége) de teus trabalhos! Falando-me (diegesámenos) do renome que tens, terás prazer e eu, ouvindo do começo ao fim os feitos de um homem belo e bom e deles tendo tirado uma lição, se disso for capaz, serei muito grato a ti. - Mas, por Zeus! disse (éphe) Iscômaco. É com muito prazer que te narrarei (diegésomai) o que estou sempre fazendo" (Xenofonte, Econômico, XI, 1-2). Esta passagem apenas prepara o que vem a seguir, ou seja, a exposição do modo de agir de Iscômaco, após uma interrupção de Sócrates, sendo, portanto, imediatamente anterior à que se reproduz no

\footnotetext{
${ }^{8}$ As palavras entre colchetes constituem acréscimos de termos presentes no texto grego e, no primeiro caso, de pequena modificação que faço na tradução de Prado.
} 
próximo item.

g) "Já que a lei divina permite que eu venha a ser um homem bom, conta-me (diegoû) tudo sobre teus feitos para que, na medida em que for capaz de aprender ouvindo-te, eu também, a partir de amanhã, tente imitar-te. É um bom dia, disse (éphen) eu, para começar a praticar a virtude. - Tu estás brincando, Sócrates, disse (éphe) Iscômaco, mas, apesar disso, exporei (diegésomai) a ti os princípios que tento seguir o melhor que posso, no transcurso de minha vida" (Xenofonte, Econômico, XI, 6-7). A exposição estender-se-á até o final do texto, compreendendo a descrição dos modos de agir que Iscômaco considera os melhores e a reflexão sobre os mesmos, tudo entremeado pelas interferências de Sócrates, que continua a atuar como personagem e narrador.

\section{O campo semântico de diegeîsthai}

Esses exemplos, não sendo exaustivos, são todavia suficientes para permitir-nos ampliar a concepção do que seja diegeîsthai, que, em português, além da acepção comum de narrar, cobre também os sentidos de relatar, contar, expor. Acredito que o termo com que teria mais correspondência seria discorrer, por guardar a idéia de que se procede a um percurso (conforme o correspondente latino discurrere, 'correr para diferentes lugares, correr de todos os lados', cf. César, B. civ. 3, 105, 3; Virgílio, Georg. 4, 292; e 'correr, espalhar-se', cf. Quinto Cúrcio, 4, 1). Uma vantagem de adotarmos essa acepção geral está em que o verbo discursare, ainda em latim, significa 'ir e vir', 'andar a correr por diversas partes' (cf. Quintiliano, 11, 3, 126), bem como o substantivo discursus tem o significado de 'o correr, ou discorrer, para diversas partes', 'agitação', 'idas e vindas' (cf. Tito Lívio, 37, 24, 2), e ainda 'o discurso', 'a dissertação', 'a conversa'. Ora, hegeîsthai, de que deriva diegeîsthai, encontra-se também no campo semântico dos deslocamentos, significando 'ir à frente', 'conduzir', 'guiar', e ainda 'considerar', 'crer', sentidos presentes também em diérkhomai, diexérkhomai, díeimi, 'percorrer', 'percorrer com a palavra', 'expor', 'explicar', e no substantivo diéxodos, 'trajeto', 'exposição', 'descrição' (cf. Fournier, 1946, p. 51 e 59).

Caso se percorra toda a relação de exemplos acima arrolada, se poderá constatar como 'discorrer sobre' se aplicaria à totalidade das situações, além de o verbo admitir o uso intransitivo, podendose, portanto, como em grego, 'discorrer com alguém'. Entretanto, além da mera descoberta de um termo português que mais se aproximaria dos sentidos de diegeîsthai, importa reter três conclusões: a) o papel indispensável que tem quem discorre (o narrador, o expositor, o contador), mesmo porque o discurso não prevê um percurso pré-determinado, havendo uma grande abertura de possibilidades quanto a isso, o que faz com que ele possa, como nos diálogos socráticos, espraiar-se por diversas direções, perfazer idas e vindas, noutros termos, ficar inteiramente à mercê daquele que o profere; b) o segundo aspecto diz respeito ao papel do destinatário (ou narratário), que também pode interferir (e geralmente o faz) nos rumos da exposição; c) por último, considerando-se os objetos, pode-se discorrer não só sobre fatos (como na acepção comum de narrar, podendo os mesmos ser ficcionais ou históricos), como sobre situações, planos, costumes, aspectos, motivações, vidas e argumentos, sobre a natureza, o corpo, a saúde, a doença, aquilo que se viu ou se ouviu - ou mesmo simplesmente discorrer com alguém, no sentido de conversar, caso que talvez se revele o mais básico, já que, quando se discorre, o que se põe em relevo é o percurso, ou, dizendo-se com mais propriedade: o próprio discurso.

Uma derradeira observação: pelo que tudo indica, no quinto século diegeîsthai constitui um termo novo, que recorta sua especificidade no campo semântico em que outros verbos de dizer se situam. Isso explicaria, por exemplo, por que está quase ausente em Heródoto (480-420) e Tucídides (455-404), cuja profissão é narrar. Com efeito, é nos autores que produzem mais para fins do citado século até datas, algumas vezes, bem avançadas do seguinte que sua ocorrência tende a crescer, nomeadamente em Lísias (440-380), Isócrates (436-338), Xenofonte (430-355) e Platão (427/428-347). Seu uso, no contraponto com outros verbos da esfera de dizer, parece referir-se a que se fale sobre um fato, uma pessoa ou um argumento com algum detalhe, fazendo com que 
diegeîsthai concorra, principalmente, com o antigo katalégein, que, de Homero até Heródoto, cobre o sentido de 'expor em detalhe', 'contar', ou mesmo venha a substituí-lo (com efeito, tendo esse sentido, katalégein é raro no ático e na koiné).

\section{DE VOLTA A PLATÃO}

Desclos, investigando o que se encontra "à margem dos diálogos de Platão", chama a atenção para seu principal movimento: num contexto em que os novos discursos, em prosa, ainda não foram objeto de definição, a "operação de partilha encontra sua origem e explicação num empreendimento, sem precedentes na Antiguidade, de delimitação dos campos do saber", ou seja, o que há de mais importante nos diálogos é esse esforço de horízein, delimitar, marcar as fronteiras e distinguir, provendo a temas urbanísticos e geográficos, de cosmologia e representação do corpo humano, de ética e política - no que se incluiria também, sem dúvida alguma, a reflexão sobre a poesia e outros gêneros de discurso - "um de seus pontos comuns", talvez mesmo o ponto mais comum que articula o que, desde então, se entende por philosopheîn (Desclos, 2003, p. 16; 8-9). Considero que é dessa perspectiva que se deve entender a reflexão platônica sobre a poesia, ou, noutros termos, de seu esforço de pensar a cultura é que decorre a necessidade de pensar a poesia, o que leva à teorização voltada para responder, sobretudo, às questões levantadas pela recepção dos poetas.

Assim, o que parece mais relevante é que a ênfase dada à diegese responde à necessidade de delimitação a que em geral se visa. Não se deve menosprezar o fato de que Platão procede a autênticas experimentações diegéticas, produzindo peças cuja léxis se classifica tanto como a pura "diegese mimética", em diálogos sem nenhum enquadramento, como Eutifron e Críton, quanto como diegese mista, sobretudo na própria República, concebida como um longo relato de Sócrates. $\mathrm{O}$ experimentalismo estende-se ainda à técnica de enquadrar diegeses em diegeses, de que o Banquete seria um exemplo dos mais refinados. Em especial, esse interesse se comprova sobejamente no Teeteto, em que, após a abertura inicial em diegese mimética, envolvendo Euclides e Terpsíon, se passa à leitura do memorial (hypómnema) escrito pelo primeiro a partir da diegese mista que lhe fizera certa vez Sócrates de seu diálogo com o jovem que dá título à obra, com a diferença de que, ao escrevê-lo, Euclides o fizera passar dessa categoria à de diegese mimética ${ }^{9}$. Essa exploração da diegese nos diálogos platônicos deve garantir-nos que ele parece compreendê-la como a espécie de discurso mais apropriada, senão a única possível, ao que concebia como philosophía.

É provavelmente por essa razão que lhe cumpre definir, do modo mais exato possível, o que é a diegese dos poetas, o que significa delimitá-la (horízein) a certo horizonte deôntico. Ora, se a diegese é uma das espécies de dicção (léxis) que pode assumir o discurso (lógos), distinguindo-se em especial da erística, com suas perguntas e respostas breves, ela, mesmo assim, se mostra capaz de inserir-se em outras espécies de lógos, incluindo a dialética ${ }^{10}$. Nesse sentido, o primeiro traço distintivo da dicção dos poetas é que tudo quanto eles dizem, de cabo a rabo, é apenas e tão somente diegese, contrariamente ao que se encontra em outros discursos, como o do médico, do historiador,

\footnotetext{
${ }^{9}$ Comentei esses artifícios em Brandão, 2007, 361-366. O caso do Teeteto é de especial importância para observar o quanto Platão tem consciência dos recursos oferecidos pela diegese e de como os explora. Com efeito, afirma Euclides a Terpsíon: "escrevi então o lógos não com Sócrates narrando-me (diegoúmenon), como narrou (hos diegeîto), mas dialogando (dialegómenon) com os que disse ter dialogado (...). Assim, a fim de, no escrito, por conveniência, não introduzir as diegeses entre os lógoi, tanto as relativas a ele próprio quando dizia Sócrates: 'e eu disse', ou 'e eu falei' -, quanto as relativas ao que respondia - como 'ele concordou' ou 'não se pôs de acordo' -, por isso escrevi como se ele estivesse dialogando com seus interlocutores (autòn autô̂s dialegómenon), tendo eliminado aquele tipo de coisas." (Teeteto, $143 \mathrm{~b}-\mathrm{c})$

${ }^{10} \mathrm{Cf}$. Górgias, 465e, em que Sócrates, após uma longa argumentação, em que busca demonstrar que a retórica é para a alma o que a culinária é para o corpo, declara: "quando eu falava brevemente, você não entendia, nem era capaz de aproveitar nada da resposta que eu lhe dava, mas tinha necessidade de diegese".
} 
do orador e do próprio filósofo. Com o lógos desses, que todavia pode conter partes diegéticas, é que cumpre estabelecer a partilha, parecendo em especial relevante mostrar por que o poeta não é filósofo. Ele não o é, em primeiro lugar, porque seu discurso é pseûdos no todo em que apenas há algo de verdadeiro; ele também não o é porque sua dicção é pura e simplesmente diegética.

Esses dois critérios, no nível do discurso e da diç̧ão, parecem suficientes a Platão para definir o poético. O que eles têm de próprio é entregar o recebedor inteiramente à condução do diegeta, pois se não é o verdadeiro, como com relação ao filósofo, nem o mundo a que o discurso remete, no caso do historiador ou do médico, nem algum tipo de argumentação, como aquela à qual apela o orador, se não é nada disso que garante a autoridade da diegese, então sua validade se assenta tão somente nas qualidades da própria dicção poética. É verdade que a definição platônica comporta o complemento de que a diegese dos poetas é "sobre coisas que foram, são ou serão" (è gegonónton è ónton è mellónton), o que poderia implicar uma dimensão de temporalidade que justificasse considerar que se tivesse em vista apenas os gêneros narrativos. Ainda que isso pudesse implicar numa organização como a aconselhada por Isócrates, de que "se deve narrar o que aconteceu em primeiro lugar, em segundo lugar e o restante seqüencialmente" (diegetéon dè tò prôton kaì tò deúteron kaì tà loipà hepoménos), o que estaria em concordância com as práticas narrativas em geral e encontraria fundamentação nas declarações metatextuais de Homero e Hesíodo ${ }^{11}$, acredito que não se trata de definir a diegese a partir do uso de alguma forma de marcação cronológica, mas de remeter a uma organização do próprio discurso tendo em vista a temporalidade da dicção. Um poeta que, como Safo, faz referência a suas afecções em decorrência da visão da pessoa amada, produz diégesis tanto quanto a epopéia ou o teatro. Isso porque a diegese que não é mais que diegese, enquanto relato de fatos cronologicamente organizados ou não, independe de comprovações e argumentação, bastando-lhe a palavra do próprio diegeta.

Se parece fácil compreender por que um discurso (lógos) que se define como pseûdos seria considerado altamente problemático - e perigoso para o recebedor - , como é o dos poetas, mais difícil se torna entender por que uma dicção (léxis) que se reduz a simples diegese se consideraria igualmente problemática e perigosa. Não é por ser "narrativa", nem por contar sucessos, pois isso também fazem outros tipos de diegetas, em especial o historiador, mas, acredito, porque ela se fecha em si mesma e tira de si mesma seu valor. Evidentemente que as diferentes espécies de dicção diegética dos poetas supõem um acréscimo de problemas e perigos, na medida em que se tornam mais miméticas. Note-se bem: um poema em que o poeta fala como si mesmo e não mudando, ou seja, uma forma bastante comum no campo da chamada lírica, não é menos diegese que a narrativa homérica. Como esta, também aquele cria, através justamente da diegese do poeta, um universo que encontra em si seu próprio critério de coesão. E quanto mais mimética for a diç̧ão, mais ela se assemelhará ao mundo, em vez de justamente indicar, para seu recebedor, que constrói um mundo à parte, entregue à condução do poeta. Noutros termos: decerto a mimese acrescenta à dicção do poeta graus diferentes de ilusão, tornando menos fácil de nela discernir-se o poético, mas não é o mimético, para Platão, que dá identidade ao poético, mas o diegético, tanto que uma das modalidades de léxis possível aos poetas é a da diegese simples (haplè diégesis), em que não se percebe nada de mimese.

Modalidade não só possível, mas, ao que parece, mais rara e preferível porque é nela, com mais clareza, que o poeta se mostra como poeta, o poema enquanto poema e, enfim, a poesia no que ela é.

\footnotetext{
${ }^{11}$ Trabalhei esses elementos em Brandão, 2005, especialmente p. 91-114, entendendo que o que a Musa ensina ao aedo é justamente como produzir um canto, conforme as palavras que Ulisses dirige a Demódoco na corte dos feácios, katà kósmon e katà moîran.
} 


\section{BIBLIOGRAFIA ${ }^{12}$}

BRANDÃO, Jacyntho Lins. Antiga Musa: arqueologia da ficção. Belo Horizonte: Faculdade de Letras da UFMG, 2005.

Homero do grego para o grego. Asa-Palavra, Brumadinho, v. 1, n. 3, p. 15-29, 2005.

Diegese em República 392d. Kriterion, Belo Horizonte, v. 48, n. 116, p. 351-366, 2007.

CANFORA, Luciano. Um ofício perigoso: a vida cotidiana dos filósofos gregos. Tradução de Nanci Fernandes e Mariza Bertoli. São Paulo: Perspectiva, 2003.

CRESPO, Emilio, CONTI, Luz, MAQUIEIRA, Helena. Sintaxis del griego clásico. Madrid: Gredos, 2003.

DESCLOS, Marie-Laurence. Aux marges des dialogues de Platon. Grenoble: Jérôme Millon, 2003. FOURNIER, H. Les verbes de "dire” en Grec ancien (exemple de conjugaison supplétive). Paris: Librairie C. Klincksieck, 1946.

GENETTE, Gérard. Genres, “types”, modes. Poétique, Paris, v. 32, p. 389-421, 1977.

MARQUES, Marcelo Pimenta. Platão, pensador da diferença: uma leitura do Sofista. Belo Horizonte: Editora UFMG, 2006.

MINER, Earl. Poética comparada. Tradução de Angela Gasperin. Brasília: Editora Universidade de Brasília, 1996.

SCHÜLER, Donaldo. Heráclito e seu (dis)curso. Porto Alegre: L\&PM, 2000.

SPINA, Luigi. Platone "tradutore" di Omero. Eikasmos, Bologna, v. 5, p. 174-179, 1994.

XENOFONTE. Econômico. Tradução de Anna Lia Amaral de Almeida Prado. São Paulo: Martins Fontes, 1999.

${ }^{12}$ Os textos antigos não referidos aqui são citados, normalmente, a partir das edições críticas da Coleção Budé (Les Belles Lettres), em traduções minhas. 